\title{
A FASCINATING SYNTHESIS OF SCIENCE, THEOLOGY, AND SPIRITUALITY: ST. GREGORY PALAMAS
}

\author{
Rev. PhD. Alexandru-Corneliu ARION \\ Assoc. prof., Faculty of Theology and Sciences of Education, \\ "Valahia" University of Târgovişte, ROMANIA \\ Email: alexcoarion@yahoo.co.uk \\ Motto: «Any word can be contradicted by another, but \\ can word contradict life? » (St. Gregory Palamas)
}

\begin{abstract}
As a prominent Church father, mystical theologian and incisive polemicist, St. Gregory Palamas has realized a "Summa Theologica» of his epoch, but one that has surpassed not only the thinking of contemporaries, but remained, to this day, a synthesis of philosophical and theological knowledge, at least for the Eastern Christianity. He pointed out with clarity the independence of theology from philosophy or from any other field of research. One of the most important instruments with a view to knowing God is prayer and Palamas began to write under the pressure of defending the hesychastic method of prayer. He proves that true communion with God was possible through sanctification and that God's vision through prayer was a sign of this spiritual communion. In Palamas' very coherent theological thinking, Christology corresponds to his anthropology, and both to his mysticism. St. Gregory strongly depreciated the value of intellectual effort, maintaining the primacy of direct illumination over scientific reasoning. Thus, prayer and asceticism engender love, which leads to illumination by God and participation in the divine life. He tries to make sense of mystical experience in the scientific and philosophical language of his day. Paradoxically, almost every attempt arrives at establishing that the spiritual cannot be grasped by man's natural intellectual capacity, nor expressed in philosophical language. But the spiritual man can be the partaker of this experience through the experience of grace, as divine uncreated energy, the true "face" of God accessible to human contemplation. The Archbishop of Thessaloniki, who realized a synthesis of Science, Theology, and Spirituality outlines the relation between them as follows: Science explores the world and leads to technological inventions; Theology interprets reality within the Christian framework, evidencing the glory of God as reflected throughout his creation; and Spirituality is the privileged path toward personal transformation. The debate about Palamism is likely to continue for some time. His version of theosis (deification) was enshrined in Orthodox teaching as a result of his canonization, but among the intellectuals for whom it was intended it remained controversial, despite its grandeur.
\end{abstract}

Keywords: science; theology; spirituality; mysticism; uncreated energies; nature; deification; ascetism; illumination; divine grace; 


\section{INTRODUCTION}

Looking for an alternative to the Western medieval context that led to the dissociation of science, theology and spirituality, the present study explores a distinctive paradigm, namely the cultural framework of Byzantium of the fourteenth century. In my opinion, the antagonism between science and theology, along with modern disinterest in the spiritual path, could have been avoided if Byzantine culture had been taken seriously in the West. Therefore, my aim is to emphasize the relevance of the Byzantine solution - as illustrated by its famous representative of the fourteenth century: St. Gregory Palamas - for the current efforts of the last decades to link the domains.

As a prominent Church father, mystical theologian, spiritual guide and incisive polemicist against non-ecclesiastical epistemology, St. Gregory Palamas (1296-1359) presents an impressive command of the "profane arts" in one of his later writings. This work, entitled: Topics of Natural and Theological Science and on the Moral and Ascetic Life: One Hundred and Fifty Texts ${ }^{1}$, shows (mainly in chapters 1-29) the author's balanced understanding of the natural sciences, together with his genuine aptitude for logic and scientific reasoning. It also demonstrates the impressive discernment of Palamas, who skilfully pursues the specific abilities and possible points of interaction between theology and science without, however, interfering with each other ${ }^{2}$.

St. Gregory Palamas is known as a Byzantine spiritual author, a remarkable theologian, and a polymath. However, when not considered highly controversial by his opponents, for many contemporary authors the Palamite heritage tends to be reduced to its doctrinal and spiritual dimensions. For example, despite his meritorious undertakings for a holistic description of Byzantine culture, the Greek philosopher Basil Tatakis completely ignores the scientific side of Palamas' training under Theodore Metochites and makes no reference to his balanced approach to science. Moreover, this approach, excellently illustrated by Topics, $1-29^{3}$ represents a progress from the general reluctance manifested by his master against natural philosophy and our cursive cognitive skills. ${ }^{4}$ Unfortunately, his efforts to integrate science, theology, and spiritual life into a hierarchical scheme that anticipates the transdisciplinary vision are less known and neglected both in the Church, as well as outside it.

\section{SCHOLARS AND EXPONENTS OF TRADITION OF THE BYZANTINE 14th CENTURY}

In 1330, Barlaam of Calabria (d. 1348), a Greek monk from southern Italy, went to Thessaloniki and Constantinople in an attempt to prove that "Western" barbarians were capable of philosophy, mathematics, and science ${ }^{5}$. It came to be publicly ridiculed by the well-known Byzantine scholar Nikephoros Gregoras (d. 1360), who claimed that the "barbarians" remained loyal to Aristotle, while the Byzantines advanced beyond this point. It

\footnotetext{
${ }^{1}$ Saint Gregory PaLAmAS, The one hundred and fifty Chapters, edited and translated by Robert E. Sinkewicz, C.S.B., Pontifical Institute of Mediaeval Studies, Toronto, Ontario, Canada, 1988.

${ }^{2}$ Doru CostaCHE, "Queen of the Sciences? Theology and Natural Knowledge in St Gregory Palamas' One Hundred and Fifty Chapters", in Transdisciplinarity in Science and Religion, Bucharest, Curtea Veche Publishing, nr. 3/2008, p. 27.

${ }^{3}$ Ibidem, pp. 31-34.

${ }^{4}$ Börje BYDÉN, “To Every Argument there is a Counter-Argument”: Theodore Metochites' Defence of Scepticism (Semeiosis 61), in Katerina IERODIAKONOU (ed.), Byzantine Philosophy and Its Ancient Sources, Oxford, Clarendon Press, 2002, pp. 184, 198.

${ }^{5}$ See Stavros Yangazoglou, "Philosophy and theology: The demonstrative method in the theology of St. Gregory Palamas”, in The Greek Orthodox Theological Review, 41, 1 (1996), p. 3.
} 
doesn't matter here how correct or wrong Gregoras' argument was; nor does it matter how well informed or misinformed he was about the West. What matters is the awareness that he expressed that, after centuries of cultural and civilizational development, although still in love with Aristotle (at least from the significant synthesis made by St. Maximus the Confessor in the seventh century), the Byzantines had gone beyond any servile approach to the legacy of Aristotle.

But together with the necessity of revaluating Byzantine science, another aspect is of interest here: almost all the protagonists of the fourteenth century were likewise convinced Christian believers. As such, they illustrated a holistic culture where the gaps between science, technology, theology, and spirituality were inexistent.

The profile of the medieval scholar, both a scientist, and a theologian was perfectly embodied by a genuine sage whose name has already become familiar. We refer here to Theodore Metochites, an imperial dignitary and logician, an Aristotelian teacher and a true sceptic, astronomer, and mathematician, a benefactor of the famous church of Chora and defender of the Byzantine theological tradition. This last aspect is emphasized by the votive painting of Chora depicting Metochites as a devout believer, kneeling before Christ. In light of this depiction and of the contributions of a series of contemporary researchers (J. Meyendorff, Alexei Nesteruk, S. Yangazoglou), the idea of a secular scholarship in Byzantium is no longer tenable. ${ }^{6}$ Whilst a direct mentor of many fourteenth century scholars, among whom feature the equally famous Nikephoros Gregoras and St. Gregory Palamas, Metochites exercised a powerful and lasting influence upon the Byzantine intellectual milieus.

Although steeped in Aristotelian logic, Metochites nurtured a deep reluctance toward our capacity of solving the undecidable conundrums of knowledge by way of logical devices as syllogisms. More precisely, as a promoter of "negative dogmatism", he was convinced that we could not be certain of the veracity of our grasp of the nature of things. For a good reason therefore, the attitude of this "founder of Byzantine 'humanism' in the fourteenth century" has recently been associated with ancient scepticism. Nevertheless, when considered within the ecclesial tradition to which he belonged, the attitude of Metochites perfectly matches the apophatic mindset of the mainstream early Byzantine theologians. ${ }^{8}$

The lesson of Metochite and other Byzantine scholars is clear: science and theology, technology and the spiritual life are not mutually exclusive, contributing together to the improvement of human life and the advancement of civilization. Cultivating such an attitude, the fourteenth century Byzantines seem to have perpetuated the legacy of St. Maximus ${ }^{9}$, who

\footnotetext{
${ }^{6}$ Rev. Doru Costache, "The other path in science, theology, and spirituality", in Transdisciplinary. Studies, Science, Spirituality, Society, no. 1, 2011, Bucharest, pp. 46-47.

${ }^{7}$ John MEYENDORFF, Byzantine Theology: Historical Trends and Doctrinal Themes, revised second edition, New York, Fordham University Press, 1983 (reprinted) • The Byzantine Legacy in the Orthodox Church, Crestwood, St. Vladimir's Seminary Press, 2001, p. 136.

${ }^{8}$ This is not a researched aspect, although the cross-disciplinary nature of Metochites' formation and legacy could be very relevant to any history of the conversations in science and theology. Either way, or rather both ways in his case, his approach was based on an uncompromising denial of the validity, never questioned before, of the logical principles of noncontradiction and the excluded middle when referring to the ultimate aspects of reality. See Börje BYDÉN, “To Every Argument there is a Counter-Argument": Theodore Metochites' Defence of Scepticism (Semeiosis 61), p. 186.

${ }^{9}$ Doru Costache, Going Upwards with Everything You Are: The Unifying Ladder of St. Maximus the Confessor, in Basarab Nicolescu, Magda Stavinschi (eds.), Science and Orthodoxy, a Necessary Dialogue, Bucharest: Curtea Veche, 2006, pp. 135-144.
} 
strongly believed in the possibility of a comprehensive and interactive framework in which all these pieces fit together and complement each other in a creative way.

One more question remains. If this sense of complementarity was so deeply ingrained in Byzantine culture, then why were many Byzantine scholars marginalized by mass society? The answer is simple, despite the complexity highlighted by the contemporary scholarship. Like their western counterparts, some Byzantine scholars manifested an overconfidence in the competence of philosophy (mainly, Platonic) for theological and spiritual matters, ignoring the disciplinary boundaries between the fields. But for a man like Palamas, who militated - along with the effort to better articulate the fields, for their distinctiveness and autonomy - a statement like the one professed by Barlaam, namely, theology is based on "science and knowledge", was outrageous. He pointed out with clarity, establishing the independence of theology from philosophy or any other field for that matter:

"To know God truly insofar as is possible is incomparably superior to the philosophy of the Greeks, and simply to know what place man has in relation to God surpasses all their wisdom" (Topics, 26). ${ }^{10}$

\section{KNOWLEDGE THROUGH PRAYER}

One of the most important instruments with a view to knowing God is, for St. Gregory, prayer. He began to write under the pressure of circumstances, i.e., to defend the hesychastic method of prayer. Varlaam of Calabria began the controversy when he attacked the method and the teachings involved in it, which culminated in the possibility of seeing the divine light.

Varlaam wrote his first treatises after a period of apprenticeship under some illiterate monks. They claimed - according to his account - that during the ecstatic experience of prayer, they cleanse their souls of demons that attract them through passions so that, at the end of this process, they could see the divine nature. He accused the Hesychast monks of Messalianism, the heresy that claims a material vision of $\mathrm{God}^{11}$.

The main issue in this debate was the communion with God and how this could be done. Other themes have sprung: Is such communion possible in this life? What does this communion consist in? What is the role of knowledge in establishing this communion? What kind of knowledge is involved in? How does the human mind participate in this process? Is the human body part of this experience? Is deification a gift of the future or can it be partially realized in this life? What are the theophanic manifestations of divine light in the Scripture? What is the nature of this Light? Is God accessible or inaccessible, visible or invisible?

In the context of this debate, St. Gregory undertook the mission of proving that true communion with God was possible through sanctification and that God's vision through prayer was a sign of this spiritual communion. From the very beginning, Palama refuses to identify God's vision with God's vision of nature. The nature of God was invisible, but divine light or energy is accessible to the human soul. Here appears the distinction between the transcendent, unapproachable and unknown divine being, and the divine energies which

\footnotetext{
${ }^{10}$ Rev. Doru COSTACHE, "The other path in science, theology, and spirituality", p. 48.

${ }^{11}$ Vladimir LossKY, The vision of God, New York, St. Vladimir's Seminary Press, 1983, p. 154. St. Gregory frequently cites his predecessors: Macarius the Great, Basil the Great, Gregory the Theologian, John Chrysostom, Dionysius the Areopagite, Symeon the Metaphrastes, John Climacus, Maximus the Confessor, John Damascene, Simeon the New Theologian, and others. From his perspective, the teaching about divine energies is synonymous with the teaching about divine grace that was manifested in the vision of biblical prophets and more openly in the life and person of Jesus Christ.
} 
belong to Him and which are communicated to men through the Trinitarian persons. But is this feature of Palama's theology so revolutionary?

St. Gregory observes that, along with the denial of God's experience as Revelation and personal encounter, Varlaam rejects even the revealed character of Holy Scripture. He is accused of atheism, perhaps because natural theology, based exclusively on human reason, can always find its sources of negation in the same human reason. In his interpretation of Dionysius, the Areopagite, St. Gregory is overwhelmed with wonder:

"Is it not obvious to everyone that Dionysius' apophatism is the result of a union with God? Dionysius expresses the inability of the human mind to describe the depths of this union with the divine. However, what is ineffable at the level of language is accessible at the level of experience". ${ }^{12}$

St. Gregory confesses a double Gnostic methodology: on the one hand, natural knowledge allows man to approach the natural order, and, on the other, spiritual knowledge allows man to access spiritual reality. The first is inferior to the second. Self-understanding, almost following Socrates, and knowledge of God are more important than having scientific understanding. The connection between Socratic self-knowledge and the knowledge of God is a permanent feature in Greek theology, and closer to our time, St. Nectarios of Aegina entitled his treatise on ethics "Know Yourself or About Virtues".

While for Varlaam redemption includes profane knowledge, often seen as above the virtues, for Palama it presupposes a mystical knowledge, that is, a strong and very sensitive relationship with God, expressed through unceasing prayer that culminates in the sight of the Divine Light. This light is not something that interferes between man and God; it is the very presence of God, His blessing, and His grace. The virtues prepare man for union with God, but this is given as a gift only through the prayer of the mind. The vision of the Divine Light is, therefore, the work of the Holy Spirit, given to the human soul, which is prepared for such an experience through the unceasing prayer that brings the purification of the heart. ${ }^{13}$

All that is left is to keep the commandments. This makes social life bearable and, ultimately, the promise of the inheritance of eternal goods. Salvation is thus possible without deification, and it seems that, unlike St. Simeon the New Theologian, holiness is possible without deification, and personal salvation can be attained without reaching the supernatural peaks of asceticism. This short treatise of Palama destroys an orthodox theological cliché: the one that opposes Imitatio Christi of Thomas à Kempis to The Life in Christ of Nicolaus Cabasilas, the exteriority to interiority in following Christ. Finally, the spirituality expressed by the Calabrian theologian suggests, from this point of view, the following of Christ in an accessible and less mystical way. It is not surprising that nowadays Western Christianity proposes some virtues that have a meaning for the man living in society, while Eastern Christianity still fascinates with his mysticism, but is still reluctant to social issues approach.

Varlaam's attitude about the light seen by the praying hesychast changed afterwhile. At first, he considered it a demonic illusion, but when St. Gregory wrote convincingly against it, he described it as a natural light, a created symbol that acts as an interface between God and men. In his opinion, it is simply the light of natural knowledge, a reflection of the

\footnotetext{
${ }^{12}$ St. Gregory Palamas, 150 Capete despre cunostinta naturală, despre cunoașterea lui Dumnezeu, despre viața morală și despre făptuire (150 Chapters on natural knowledge, on knowledge of God, on moral life, and deeds), in Filocalia (Rom trans. of Philokalia), vol. VII, trans. by Rev. prof. Dumitru Stăniloae, Bucharest: EIBMBOR, 1977, p. 126.

${ }^{13}$ Rev. Nicu DuMITRAȘCU, Bucuria iluminării divine la Sfântul Grigorie Palama (The joy of divine enlightenment on St. Gregory Palamas), in Teologie şi viaţă isihastă în opera Sf. Grigorie Palama (Theology and hesychastic life in the work of St. Gregory Palamas), Mitropolia Olteniei, Craiova, 2010, p. 179.
} 
mind on it, the inner illumination of an intelligent brain that possesses scientific and philosophical understanding. From his point of view, Palamas' insistence on the uncreated nature of divine light ruins the simplicity of God, thus, drawing upon him the accusation of ditheism.

In fact, St. Gregory Palamas' opponents professed a kind of intellectualism of Oriental origin. To them, divine light and union with God in this life were mere metaphors. To defend himself, St. Gregory often resorted to Christology. Inevitably, the controversy highlighted the famous biblical episode of the Transfiguration of Christ on Mount Tabor. St. Gregory resumes the patristic tradition when he claims that the apostles perceived the divine light in the presence of the transfigured Christ. The Lord of glory does not change in this case, but the eyes of the Apostle change for a moment. They could contemplate the divine light, flowing from His divinity through the veil of His assumed humanity. As God Himself, this light is both uncreated and eternal, communicating to us not a substitute for God, but God Himself. ${ }^{14}$

The Transfiguration is not just about the Lord, but about the eyes of the apostles, who have undergone a transmutation. They were thus able to see the invisible, to understand the incomprehensible. At this point, St. Gregory quotes a patristic authority:

"Behold John Damascene, who is wise concerning divine things: Christ is transfigured, not by putting on qualities he did not possess before, nor by changing into something He has not been until now, but by revealing to His disciples who He really was. For, remaining identical with what had been before, He appeared to the disciples in His splendour; He is veraciously the true light, the radiance of glory." 15

Saint Gregory explains that, in the case of the Hesychast, this sight is, in fact, a union with the light, and the vision is granted by the Holy Spirit; in the frame of vision-union, the beholder himself becomes a light who sees light with the help of light:

"So to go back - contemplating this light is a union, even if it does not withstand the imperfect order. But is union with this light other than a vision? And since it is caused by the cessation of intellectual activity, how could it be accomplished if not by the Spirit? For in the light the light is seen, and what it sees operates in a similar light, because this faculty has no other way of functioning" 16 .

Some years later, a letter sent by Saint Gregory to the nun Xeni echoes the above famous passage from the Triads. In a significant fragment, he describes the mind's ascension to God in light. Spiritual ascension begins with the mind's purification of every sinful passion and with the return to itself. After passing beyond all mental and material images and meanings, the mind is transformed through the work of grace, which shines with unspeakable light in the inner man. Using the light as a pathway, the nous ascends above everything through the power of the Holy Spirit, gathers a spiritual sense through which the unheard is heard, and sees the unseen and participates with the One who is above everything. ${ }^{17}$

Palamas' theological thinking is very coherent. His Christology corresponds to his anthropology, and both to his mysticism. According to Fr. Fadi Georgi:

\footnotetext{
${ }^{14}$ Vladimir LOSSKY, The vision of God, p. 156.

${ }^{15}$ St. Gregory Palamas, "Hyper tõn hierõs hesychazontön", in: B. BobRinsKY, P. PAPAEVAGgELOS, J. MEYENDORFF \& P. XRESTOU (eds.), Syggramata I, Thessaloniky: Oikos Kyromanos, 2010, p. 427.

${ }^{16}$ Ibidem, p. 432.

${ }^{17}$ St. Gregory Palamas, Pros Xenin monahin, în „P. Xrestou (ed.), Syggramata V, Thessaloniki: Oikos Kyromanos, 1992, pp. 223-224.
} 
"Palamas considers the redeeming work of Christ as the foundation of the theology of light. In this theological frame, the fall of Adam is represented as his separation from Beauty and Light and as the alienation from the divine form and the original destiny of humanity". ${ }^{18}$

Created in the image of God, man realizes the likeness by union with God. In this way, he regains the lost beauty of holiness. In paradise, Adam was clothed in with a garment of light, which he eventually lost through original sin. On Mount Tabor, Christ gives to the human being this shining garment. His transfiguration is an anticipation and sampling of our eschatological transfiguration. But even in the present time, the true Christian foretastes the future state when "the righteous will shine like the sun in the kingdom of their Father" (Matthew 13:43) ${ }^{19}$. The method of the hesychast is only the activation or rediscovery of the Sacrament of Baptism, which gives man the deifying light of grace. ${ }^{20}$

The question of uncreated grace remains, more than ever, "an issue between the East and the West." So that, for Antoine Levy, for example,

"The controversy between Gregory and Barlaam does not refer only to a dogmatic point, but also the status of the theologian and the very legitimacy of his research were at stake. Who, in fact, had the authority to tell the truth about God? The one whose intelligence had been impregnated by attendance to the philosophy and secular sciences (Barlaam) - or the one whose spiritual experience had been grown into a life of asceticism and prayer (Gregory Palamas)?,21

For the whole ascetic Tradition, to which St. Gregory Palamas refers, prayer is the means of man's ascension to God. "The unceasing remembrance of God in prayer" gives man the enlightenment of the Holy Spirit, once the worldly worries no longer interrupt the continuity of remembrance, and man becomes through prayer the church of God. ${ }^{22}$

This aspect was revealed by Christ while he was praying, in the light, on Mount Tabor. That is why the Church Fathers teach that "the end of prayer is the rapture of the Lord," and call enlightenment "purified mind," which clarifies the light of the Holy Trinity during prayer. Then the mind rises above the prayer. This state is no longer called prayer, but "the birth of pure prayer," which is accomplished by the Spirit. Then the mind rises above the prayer and we contemplate the glory of the divine nature, the glory and the light, which is, according to the Patristic Tradition, around the divine and happy nature. ${ }^{23}$

But this uncreated and above the heavens glory of God was seen by Saint Archdeacon Stephen with his own eyes, beyond the possibility offered by the senses. The

${ }^{18}$ Rev. Fadi GEORGI, "The vision of God as a foretaste of eternal life according to Saint Gregory Palamas", in M. TAMCKE (ed.), Gotteserlebnis und Gotteslehre: Christliche und islamische Mystik im Orient. Göttinger Orientforschungen Syriaca 38, Wiesbaden: Harrassowitz Verlag, 2010, p. 149.

${ }^{19}$ Metropolitan Hierotheos VLACHOS, Saint Gregory Palamas as a Hagiorite, Levadia: Birth of Theotokos Monastery, 2000, pp. 339, 342.

${ }^{20}$ Jean MEYENDORF, St. Grégoire Palamas et la mystique orthodoxe, Paris: Editions de Seuil, 1959, p. 118.

${ }^{21}$ Antoine LEVY, Le créé et l'incréé: Maxime le confesseur et Thomas d'Aquin: aux sources de la querelle palamienne, Paris: Vrin, 2006), p. 16.

${ }^{22}$ See HAUSHER I., Nom du Christ et voies d'oraison, OCA, Roma 1960; BEHR-SIEGEL E., ’La prière de Jesus ou le mystère de la spiritualité monastique orthodoxe”, Dieu Vivant 8 (1947), pp. 69-94; WARE K., „Pray without Ceasing: The Ideal of Continual Prayer in Eastern Monasticism”, ECR 3 (1969), pp. 253-261; GARDET A., „Un problème de mystique comparée: La mention du Nom Divin (dhikr) dans la mystique musulmanne”, Revue Thomiste 52 (1952), p. 642-679; 53 (1953), pp. 197-216; NASR S.H., „,The Prayer of the Heart in Hesychasm and Sufism", GOTR 1-2 (1986), pp. 195-204.

${ }^{23}$ Rev. Porphyrios GeORgi, Inviere și viață. Eshatologia Sf. Grigorie Palama (Resurrection and life. Eschatology of St. Gregory Palamas), Translated from Greek by Ştefan L. Toma, Andreiană, Sibiu, 2015, p. 173. 
mode of this view is identified with the way in which angels, as created beings, see eternal glory.

\section{THE GRAND SYNTHESIS OF KNOWLEDGE BY PALAMAS III.1. Philosophical Method}

From the beginning philosophical issues were at the forefront. The central problem concerned the nature of divine knowledge. Palamas opens the First Triad with the question: 'How can one demonstrate by rational argument (logoii) the good that is beyond reason?' He was replying to a questioner who had asked him about the value of secular studies and had reported the argument that by studying phenomena one can arrive at their inner principles, their $\log \bar{o} i$, which can be traced back to the mind of the Creator. Hence intellectual work "the methods of distinction, syllogistic reasoning and analysis"- can raise us up to the mind of God and conform us to his likeness - a kind of do-it-yourself theosis. ${ }^{24}$ This caricatured somewhat the views of Barlaam, who though confident that by sheer intellectual effort human reason could arrive at the limits of what was knowable, as Plato and Aristotle had done, held the inner life of God to be inaccessible to human knowledge. ${ }^{25}$ Palamas strongly depreciated the value of intellectual effort, maintaining the primacy of direct illumination over scientific reasoning.

Christ, he said, did not say, 'if you would be perfect, acquire a secular education, study mathematics, devote yourself to the science of beings. ${ }^{26}$

The beginning of contemplation and divine wisdom is the fear of God, expressed in a life of prayer and asceticism, which engenders love, which leads to illumination by God and participation in the divine life.

If Palamas had stopped there, there might have been no subsequent controversy. Barlaam claimed that he and Palamas did not differ in their epistemology, Akindynos had no special competence in philosophical questions, and Gregoras appeared to be in agreement with Palamas over the limitations of the human mind. Indeed, as an opponent of Aristotelian methodology, Gregoras believed that the syllogism was a tool for second-rate minds unable to ascend to true knowledge. ${ }^{27} \mathrm{He}$ held true knowledge to be the result of direct illumination, though in his case he interprets this as the mind's freeing itself perfectly from material images (amorphia) rather than attaining to a vision of some object other than itself. ${ }^{28}$

But Palamas did not stop there. He attempted to give an explanation of how human beings are transformed by God in terms of real experience, in terms, that is, of a vision of light which is at once both perceptible and completely spiritual. This led to his postulating a real distinction in God between that aspect which is imparticipable and transcendent - the divine essence - and that aspect in which human beings can participate - the divine energy. "The latter", Akindynos correctly reports, "he calls theosis and power and energy and grace and illumination and form and essential and natural glory of God, being different as he says

\footnotetext{
${ }^{24}$ Gregory PALAMAS, Triads 1, edited with an introduction by John Meyendorff, translation by Nicholas Gendle, preface by Jaroslav Pelikan, Paulist Press: New Jersey, 1983, first question (ed. Perella, 272).

${ }^{25}$ See SinKEWICZ, "The Doctrine of the Knowledge of God," esp. 202-12. Barlaam believed that God could only be known through his creation as cause.

${ }^{26}$ PALAMAS, Triads 1.1.5 (ed. Perella, 282).

${ }^{27}$ GreGORAS Florentios lines 932-35, ed. P. L. M. Leone, Fiorenzo o intorno alla Sapienza [Naples: Université di Napoli, 1975], p. 96, apud Norman RUSSELL, "Theosis and Gregory Palamas: Continuity or doctrinal change?", in St Vladimir's Theological Quarterly 50:4 (2006), p. 357.

${ }^{28}$ D. N. Moschos, Platonismos ë Christianismos? Oi philosophikes prohypotheseis tou Antihësychasmou tou Nikèphorou Grigora (1293-1361) (Athens: Parousia, 1998), p. 195.
} 
from his essence and nature." 29 Philosophical critics objected to Palamas' assigning ontological status to divine attributes which in fact could only be distinguished conceptually. ${ }^{30}$ Gregoras felt that Palamas was actually reviving the Platonic theory of Forms as intermediate realities between God and the created world.

As the Swedish scholar H. Gunnarsson has recently outlined, his attempt to argue his case within a contemporary philosophical framework was a bold undertaking. ${ }^{31}$ Palamas had strong reservations about the apophatic approach to divine reality. He tries to make sense of mystical experience in the scientific and philosophical language of his day. Yet paradoxically, "almost every attempt arrives at establishing that the spiritual cannot be grasped by man's natural intellectual capacity, nor expressed in philosophical language."32 Gunnarsson concludes that on the philosophical level "it is difficult to see that [Palamas' approach] meets the standards for a cogent epistemology of mystical experience." In the fourteenth century, too, not many trained in the "outer learning" were convinced if they were not already friends of the hesychasts.

\section{III.2. The dialogue between science and religion by the methodological references at St. Gregory}

Palamas distinguishes between the culture of the world, which is made with the energy of this world, and the culture of the Spirit, the true entrance into the coordinates of grace - the uncreated divine energy. Only through the practice of prayer can man open himself, mystically, to a different level of reality than the created one, namely the uncreated one, where God dwells. Theology means not the descent of the Lord through the intellectual approach of representing Him in the horizontal coordinates of human reason, but the raising of the human mind, through an intensification of the power of penetration, in the divine coordinates. Palama essentially affirms the possibility of this opening, of experiencing the real presence of God, and not in an intellectual symbolism emptied of any concrete content. The purpose of the Christian life is the deification of man by the Taboric-type living, of the experience of grace.

The hesychastic disputes of the 14th century gave the occasion of the departure from a theology of dutiful repetitiveness ${ }^{33}$ towards the decisions of the first 7 ecumenical synods to the confession of God through a theology that really embraced the issue of the epoch with the competence acquired through the work of grace. Responding to Varlaam and Akindynos by emphasizing the distinction between the essence of God, incomprehensible, and His uncreated energies, but shareable by man, St. Gregory responds, in fact, to the pressure of pagan humanism, and to the intellectual spiritualism of the Renaissance, which manifests doubt on the possibility of a real encounter-experience of God, an experience understood, rather, as a result of penetration through intelligence, at the level of creation. But God is not transcendent only to matter, but also to the work of human intelligence, hence the need for the presence of grace as an" outstretched hand" by God to man in order to overcome the wall of transcendence.

\footnotetext{
${ }^{29}$ AKINDYNOS, Letter 27.88-90 (ed. Hero, 92), apud Norman RUSSELL, "Theosis and Gregory Palamas: Continuity or doctrinal change?", p. 366.

${ }^{30}$ See Demetrios KyDONES, De personarum proprietatibus in Trinitate ad Constantinum Asanem (ed. M. Candal, "Demetrio Cidonio y el problema trinitario palamitico," OCP2S [1962]: 75-20) and the discussion in Russell, "Palamism and the Circle of Demetrius Cydones," pp. 156-57.

${ }^{31}$ See H. GUNNARSSON, Mystical Realism in the Early Theology of Gregory Palamas. Context and Analysis (Goteborg: University of Göteborg, 2002).

${ }^{32}$ GunNARSSON, Mystical Realism, p. 190.

${ }^{33}$ Jean MeYEndorfF, St. Grégoire Palamas et la mystique orthodoxe, Paris: Editions de Seuil, 1959, p. 100
} 
The saints confess God as presence-'light', a light distinct from that which we know through the senses. Tasting of this presence leads man to an experience that goes somewhat out of the natural coordinates of space-time. This experience is defended by St. Gregory as a true depth of theology, understood as a simple abstract manipulation with religious content. Theology can only be the expression of the experience of encountering God, therefore mystical. $^{34}$

In writing his Triads, Palama condemns Varlaam's two postulates, one based on Aristotelian philosophy and the other on Neoplatonist philosophy. The first states that all knowledge, including that of God, has its origin in the perception or experience of the senses. The second, using texts written by Christian authors, including Dionysius the Pseudo-Areopagite, an undisputed authority in the Church, asserted God beyond any sensible and, therefore, unknowable experience. According to Varlaam, all knowledge of God can only be but indirect; it necessarily passes through the entities perceived by the senses, and mystical knowledge can be only 'symbolically' real ${ }^{35}$.

Distinguishing between created and uncreated, two distinct ontological realities, Palama shows that the rupture between the "two levels of reality" (See this later distinction, at the eminent French physicist of Romanian origin, Basarab Nicolescu, in: $L a$ Transdisciplinarité: Manifeste, Paris, 1996) can be overcome by divine initiative, embraced by man. The spiritual man $(\pi v \varepsilon v \mu \alpha \tau \imath \kappa о \sigma)$ can be the partaker of this experience through the experience of grace, as divine uncreated energy, the true "face" of God accessible to human contemplation.

Varlaam's first postulate is thus strongly contradicted by Palama: the senses cannot be an instrument of knowledge in the world of Spirit. With regard to the second, it is clear that Varlaam did not propose a real knowledge of God, but one mediated by the world and by the symbol. Nevertheless, Palama, synthesizing the mystical tradition of the Church, wants to show precisely the fact that God can be really known, as a personal presence, the knowledge of God being not a conceptual description, but an effective union with $\mathrm{Him}^{36}$.

Varlaam considers either philosophy or theology as alternative ways of knowing God, saying that "the wisdom out of theology and the philosophy of the profane sciences have the same purpose." Given Varlaam's perspective on theology, it is not surprising that he finds them so close in their competencies. Moreover, Varlaam considers philosophy to be "the most precious thing we have." On the contrary, St. Gregory assures us that theology is fundamentally different from philosophy, because it consists in the direct and direct experience of the (super)personal presence of God.

\section{III.3.3. Aspects of the Palamite's synthesis}

Together with the mainstream Byzantine scholars, St. Gregory made considerable use of Aristotelian logic, terminology, philosophy, and science. For instance, like St. Basil the Great and St. Maximus, he consistently employed the Aristotelian term energy ( $\varepsilon v \varepsilon \rho \gamma \varepsilon 1 \alpha)$, achieving its full theological assimilation ${ }^{37}$. The appropriation of this key-concept from the Stagyrite's ontology and physics, together with a range of other elements, represents a

\footnotetext{
${ }^{34}$ Adrian LEMENI and Rev. Răzvan IONESCU, Teologie ortodoxă și știință. Repere pentru dialog (Orthodox Theology and Science. Landmarks for Dialogue) 2nd edition, EIBMBOR, Bucharest, 2007, p. 171.

35 Jean MEYENDORFF, St. Grégoire Palamas et la mystique orthodoxe, p. 111.

${ }^{36}$ Adrian LEMENI and Rev. Răzvan IONESCU, Teologie ortodoxă și știință. Repere pentru dialog (Orthodox Theology and Science. Landmarks for Dialogue), pp. 172-173.

37 Thomas L. ANASTOS, “Gregory Palamas' radicalization of the essence, energies, and hypostasis model of God”, in The Greek Orthodox Theological Review, 38, 1-4 (1993), pp. 340-345.
} 
tremendous accomplishment, shaping the mindset and discourse of Orthodox theologians for the centuries to come.

It is worth mentioning some of Palamas other contributions. Thus, it is noteworthy his courageous incorporation of scientific elements in a scripturally-based worldview ${ }^{38}$ resulting in a contextualized Christian vision of reality. This remains a highly relevant undertaking for our conversations in science and theology, from which we can still learn. Another interesting feature, denoting the cultural propensities of Byzantine intelligentsia, is St. Gregory's privileging natural explanations of cosmic phenomena against mythological ideas such as the "world soul", advocated by some Platonizing scholars (Topics, 3\&4). This naturalist stance, of an explicit Aristotelian origin, demonstrates the superficiality of the current perception about the supposed "Christian Platonism" and supernaturalism of the Byzantines.

Of particular interest is Palamas' attitude concerning logic and, more specifically, syllogisms. Although other fourteenth-century Byzantine scholars like Metochites and Gregoras - distrusted Aristotelian logic, both Barlaam, and Palamas praised its usefulness ${ }^{39}$.

Nevertheless, there was a significant difference between their views: whereas Barlaam unreservedly adhered to Aristotelian logic, Palamas cultivated a skeptical or prudent attitude, an apophatic reluctance toward the validity of the syllogistic discourse. Furthermore, alongside his mentor Metochites, St. Gregory managed to "misuse" the Aristotelian logic by relativizing the principles of non-contradiction and of the excluded middle. For example, with reference to the appropriateness of demonstrative syllogisms for the scrutiny of divine reality, he paradoxically maintained that they both are, and are not suitable to $\operatorname{God}^{40} \mathrm{He}$ solved this paradox of inclusive logic by rending the plans of essence and energy, asserting that, whilst demonstrative syllogisms are applicable to the divine energies, they are inapt in regard to God's inner life.

It is very likely that his discernment and consistent use of inclusive logic allowed Palamas, along with pondering the complementarity of science and theology, to maintain their autonomy ${ }^{41}$ and identify their different competences: science deals with the natural laws, whereas theology has the spiritual matters as its province (Topics, 20) ${ }^{42}$.

St. Gregory developed a more nuanced approach that was hierarchical in nature, working with a tripartite scheme according to which:

- Science explores the world and leads to technological inventions;

- Theology interprets reality within the Christian framework, evidencing the glory of God as reflected throughout his creation;

\footnotetext{
${ }^{38}$ D. Costache, "Queen of the Sciences? Theology and Natural Knowledge in St Gregory Palamas' One Hundred and Fifty Chapters", pp. 34-36, 38.

${ }^{39}$ Katerina IERODIAKONOU, The anti-logical movement in the fourteenth century, in Katerina Ierodiakonou (ed.), Byzantine Philosophy and Its Ancient Sources, Oxford, Clarendon Press, 2002, pp. 219-220.

${ }^{40}$ Stavros YANGAZOGLOU, "Philosophy and theology: The demonstrative method in the theology of St. Gregory Palamas", p. 10.

${ }^{41}$ See David C. LINDBERG, The Beginnings of Western Science: The European Scientific Tradition in Philosophical, Religious, and Institutional Context, Prehistory to AD 1450, 2nd edition, Chicago and London, The University of Chicago Press, 2007, p. 159.

${ }^{42}$ This distinction prevents such enthusiastic statements as A. Nesteruk's, that the Greek fathers took science as "a mode of the liturgical experience" and that "the roads of the natural sciences [...] could constitute a mode of theological experience". Similarly, the Palamite distinction between the created and the uncreated participation in God makes utterly inaccurate Nesteruk's statement that science explores "the economic activities of God in the created world". See Alexei V. NESTERUK, Light from the East: Theology, Science, and the Eastern Orthodox Tradition, Minneapolis, Fortress Press, 2003, pp. 39, 56.
} 
- Spirituality is the privileged path toward personal transformation.

From a different angle, in tune with the trajectory of ancient civilizations, Palamas seemed to have thus mapped the stages of human becoming as information, formation, and transformation (see Figure $1^{43}$ ). We should be mindful that this scheme - as already stated and in spite of the Byzantine vocabulary - could not be interpreted in terms of the superior and the inferior, referring mostly to the various degrees of competence and relevance to the process of advancement into humanization. Within such a hierarchical scheme, there is room for each domain to bring its specific contribution, an aspect abundantly emphasized by the transdisciplinary approach ${ }^{44}$, which can contribute to further our understanding of the Byzantine legacy.

Figure 1

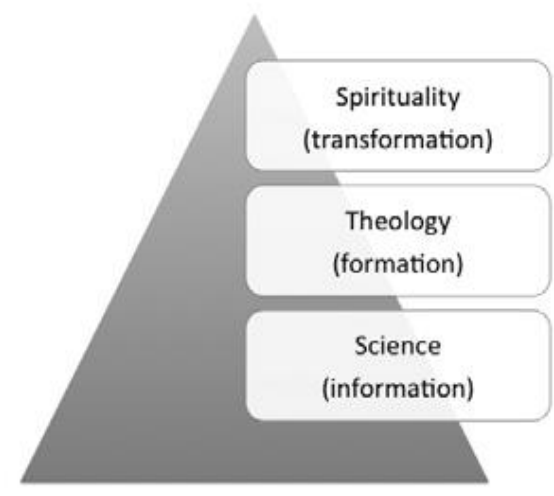

In light of the above, it becomes obvious that someone anchored in the spiritual life and theology can likewise be a practical person and a contributor to the progress of knowledge and science. This aspect is aptly pointed out by Tatakis in what may be taken as a summary of fourteenth century Byzantine culture:

"Generally speaking, mysticism, at its best moments, does not deny knowledge, the outer knowledge. What it denies is that this knowledge leads to the roots, to theory [i.e., contemplation] and to the deification of man. For this great enterprise, it summons the whole man, contracts the antinomies and, with hesychasm, gives primacy to the heart. The mind can find itself only if it is baptized in the heart."

Without being reducible to the otherwise incontestable formative dimension of the liturgical texts, as they are presented in a recent $\operatorname{article}^{46}$ the last few centuries of Byzantine development should be considered the cradle of a holistic culture that can still inspire.

\section{CONCLUSION}

St Gregory Palamas has been accused of being an innovator, and at the same time he has been honoured as a traditional theologian. Now the concepts of traditionality and innovation are closely connected with time, and apart from time neither of them can be correctly understood. But traditionality and innovation are not necessarily irreconcilable. Rather, the opposite is true; the one often supplements and completes the other. Tradition

\footnotetext{
${ }^{43}$ Apud D. Costache, "Queen of the Sciences? Theology and Natural Knowledge in St Gregory Palamas' One Hundred and Fifty Chapters", p. 51.

${ }^{44}$ Basarab NiCOLESCU, Nous, la particule et le monde, deuxième édition, revue et augmentée, Monaco, Éditions du Rocher, 2002, pp. 203-205.

${ }^{45}$ Basil TATAKIS, Christian Philosophy in the Patristic and Byzantine Tradition, trans. by G.D. Dragas, Rollinsford, Orthodox Research Institute, 2007, p. 165.

${ }^{46}$ Stanley S. HARAKAS, "Faith formation in Byzantium", in Greek Orthodox Theological Review, 50, 1-4, 2005, pp. 92-100.
} 
innovates. The most authentic innovations have been the products of tradition. Gregory Palamas, as a traditionalist theologian, was a man of innovations. His innovation was both authentic and traditional. He can therefore be very well characterized as a traditional innovator. $^{47}$

On the surface, the Palamite position is deceptively simple: God cannot be known, communicated or participated as he is in his 'essence', but is known, communicated and participated in his 'energy' or 'energies'. God may thus be said to exist in two modes, being equally fully present in both; so that the man participating in the divine 'energy' by grace is authentically sharing the life of God and is 'deified' by his participation. The energies are not identical with the hypostases of the Godhead, rather they are possessed and exercised in common by all three persons. And they are so exercised through all eternity, independently

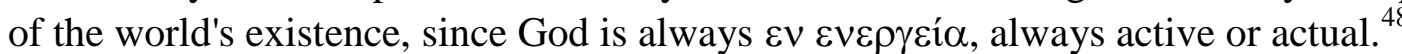

Palamas' presuppositions are three: first, that the experience of the hesychasts is real - the light they see is a real light which brings about intimate communion with the divine; secondly, that God is inaccessible in his essence; and thirdly that the Fathers convey an unchanging truth in its fullness, so that consequently the tenets of hesychasm must be found in the Fathers. The first two presuppositions account for the importance Palamas gives to the gospel account of the Transfiguration, and his innovative exegesis of it as a demonstration of theosis. The third accounts for his extended discussion of patristic texts, particularly from the Cappadocians, Dionysius and, above all, Maximus. ${ }^{49}$

During his controversial debates with Varlaam the Calabrian, Saint Gregory Palama stated that the people's findings, though they are true, do not bring any contribution to Salvation. Nothing of what is needed and useful for Salvation is missing from the teaching of the Holy Spirit. ${ }^{50}$ This straight statement of the former Archbishop of Thessaloniki could make some superficially thinking or ignorant persons question the fact that the Orthodoxy is opened to the scholars' huge range of preoccupations related to the knowledge of the world's hidden secrets. This is true, but St Gregory Palamas' statement regards the permanent reference to the Holy Book. It is not the sciences that produce the Purification of ignorance, but the Holy Scriptures and the Christian Truth ${ }^{51}$, so the renowned Saint used to say, whom we celebrate on the second Sunday of Lent. ${ }^{52}$

The debate about Palamism is likely to continue for some time. St Gregory Palamas was fond of quoting the proverb: 'Every argument can be answered by some other argument'. ${ }^{53}$ On the level of rational argumentation, theological controversy proves unending. But there is one thing, so St Gregory believed, that is always decisive: the experience of the saints. The true aim of theology is not rational certainty through abstract

\footnotetext{
${ }^{47}$ George MANTZARIDES, "Tradition and Renewal in the Theology of Saint Gregory Palamas", in: Eastern Churches Review. A Journal of Eastern Christendom, George Every, John Saward, Kallistos Timothy Ware eds., Volume IX Numbers 1-2, 1977, Clarendon Press, Oxford, p. 1.

${ }^{48}$ Rowan D. WILLIAMS, "The Philosophical Structures of Palamism”, ibidem, p. 27.

${ }^{49}$ In fact one could say without exaggeration that Palamas's spiritual theory arises from the interaction between the hesychast tradition and Maximus the Confessor. See: Norman Russell, "Theosis and Gregory Palamas: Continuity or doctrinal change?", p. 375.

${ }^{50}$ Dumitru STĂNILOAE, Viața și învățătura Sfântului Grigorie Palama (Life and Teaching of Saint Gregory

Palama), Scripta Publishing House, Bucharest, 1993, p. 27.

51 Ibidem, p. 32.

52 Răzvan IONESCU, "Water and Word - A Study of Memory", in: Transdisciplinarity in Science and Religion, Bucharest, Curtea Veche Publishing, Nr. 3 / 2008, p. 92.

${ }^{53}$ See, for example, Triads I, i, I; I, ii, question; I, iii, 13.
} 
arguments, but personal communion with God through prayer. It was as a theologian of personal experience that St Gregory was acclaimed by the Orthodox Church in the 14th century $^{54}$, and it is by the same experiential criteria that his teaching should be assessed in our own day.

The opponents of Palamism were not heretics. But, like many of the Fathers of the fourth century who had reservations about the word homoousios, they rejected novel terminology and insisted on what they took to be "the ancestral doctrines" - ta patria dogmata. Palamas' torrent of treatises convinced some of them, but his final victory was chiefly brought about by his supporters' capture of the patriarchal office. His version of theosis was enshrined in Orthodox teaching as a result of his canonization by the synod of 1368 , but among the intellectuals for whom it was intended it remained - and still remains controversial $^{55}$, despite its grandeur.

At the end, we underscore the great contribution of Palamas, that one concerning the best general description of the essence-energies distinction. It remains that which is implied by the meaning of the word energeia itself: it is the distinction between an agent and that agent's activity. In the case of God, however, we must recognize that the range of His energeiai is extremely diverse. And some are eternal and others temporal; some are contingent and others necessary; some are best conceived as 'realities' or 'energies', others as activities or operations, and yet others as attributes. ${ }^{56}$ Rather than seeking to fit this multiform concept into categories that are foreign to it, we ought to seek to understand it in its own terms, in light of the sources and concerns that shaped Palamas' thought ${ }^{57}$. Only in this way can we truly learn what he has to teach us.

\section{BIBLIOGRAPHY:}

[1] Anastos, Thomas L., "Gregory Palamas' radicalization of the essence, energies, and hypostasis model of God", in The Greek Orthodox Theological Review, 38, 1-4 (1993).

[2] BEHR-SiEgEL, E., "La prière de Jesus ou le mystère de la spiritualité monastique orthodoxe", Dieu Vivant 8 (1947).

[3] BRADShaw, D., Aristotle East and West: Metaphysics and the Division of Christendom, Cambridge University Press, 2004.

[4] - Essence and Energies: What Kind of Distinction?”, in Analogia: The Pemptousia Journal for Theological Studies, vol. 6 /2019: St Gregory Palamas, Special Series, Part 4.

[5] BYDÉN, Börje, "To Every Argument there is a Counter-Argument": Theodore Metochites" Defence of Scepticism (Semeiosis 61), in Katerina IERODIAKONOU (ed.), Byzantine Philosophy and Its Ancient Sources, Oxford, Clarendon Press, 2002.

[6] COSTACHE, Doru, "Queen of the Sciences? Theology and Natural Knowledge in St Gregory Palamas' One Hundred and Fifty Chapters", in Transdisciplinarity in Science and Religion, Bucharest, Curtea Veche Publishing, nr. 3/2008.

[7] - Going Upwards with Everything You Are: The Unifying Ladder of St. Maximus the Confessor, in Basarab Nicolescu, Magda Stavinschi (eds.), Science and Orthodoxy, a Necessary Dialogue, Bucharest: Curtea Veche, 2006.

[8] — "The other path in science, theology, and spirituality", in Transdisciplinary. Studies, Science, Spirituality, Society, no. 1, Bucharest, 2011.

\footnotetext{
${ }^{54}$ Archimandrite Kallistos WARE, “The Debate about Palamism”, in: Eastern Churches Review. A Journal of Eastern Christendom, p. 63.

${ }^{55}$ Norman RUSSELL, "Theosis and Gregory Palamas: Continuity or doctrinal change?", p. 379.

${ }^{56}$ See D. BRADSHAW, Aristotle East and West: Metaphysics and the Division of Christendom, Cambridge University Press, 2004, p. 272.

${ }^{57}$ D. BRADSHAW, “Essence and Energies: What Kind of Distinction?”, in Analogia: The Pemptousia Journal for Theological Studies, vol. 6/2019: St Gregory Palamas, Special Series, Part 4, p. 55.
} 
[9] DUMITrașCU, Nicu, Bucuria iluminării divine la Sfântul Grigorie Palama (The joy of divine enlightenment on St. Gregory Palamas), in Teologie şi viaţă isihastă în opera Sf. Grigorie Palama (Theology and hesychastic life in the work of St. Gregory Palamas), Mitropolia Olteniei, Craiova, 2010.

[10] GARDET, A., „Un problème de mystique comparée: La mention du Nom Divin (dhikr) dans la mystique musulmanne", Revue Thomiste 52 (1952).

[11] GEORGI, Fadi, "The vision of God as a foretaste of eternal life according to Saint Gregory Palamas", in M. TAMCKE (ed.), Gotteserlebnis und Gotteslehre: Christliche und islamische Mystik im Orient. Göttinger Orientforschungen Syriaca 38, Wiesbaden: Harrassowitz Verlag, 2010.

[12] GEORGI, Porphyrios, Inviere și viață. Eshatologia Sf. Grigorie Palama (Resurrection and life. Eschatology of St. Gregory Palamas), Translated from Greek by Ştefan L. Toma, Andreiană, Sibiu, 2015.

[13] Gregoras, Florentios, lines 932-35, ed. P. L. M. Leone, Fiorenzo o intorno alla Sapienza [Naples: Université di Napoli, 1975.

[14] GunNarsSon, H., Mystical Realism in the Early Theology of Gregory Palamas. Context and Analysis (Goteborg: University of Göteborg, 2002).

[15] HARAKAS, Stanley S., "Faith formation in Byzantium", in Greek Orthodox Theological Review, 50, 1-4, 2005.

[16] HAUSHER Irénée, Nom du Christ et voies d'oraison, OCA, Roma 1960.

[17] IERODIAKONOU, Katerina, The anti-logical movement in the fourteenth century, in Katerina Ierodiakonou (ed.), Byzantine Philosophy and Its Ancient Sources, Oxford, Clarendon Press, 2002.

[18] IONESCU, Răzvan, "Water and Word - A Study of Memory", in: Transdisciplinarity in Science and Religion, Bucharest, Curtea Veche Publishing, Nr. 3 / 2008.

[19] KYDONES, Demetrios, De personarum proprietatibus in Trinitate ad Constantinum Asanem (ed. M. Candal, "Demetrio Cidonio y el problema trinitario palamitico," OCP2S [1962].

[20] LEMENI, Adrian and IONESCU, Răzvan, Teologie ortodoxă și știință. Repere pentru dialog (Orthodox Theology and Science. Landmarks for Dialogue) 2nd ed., EIBMBOR, Bucharest, 2007.

[21] LEVY, Antoine, Le créé et l'incréé: Maxime le confesseur et Thomas d'Aquin: aux sources de la querelle palamienne, Paris: Vrin, 2006.

[22] LINDBERG, David C., The Beginnings of Western Science: The European Scientific Tradition in Philosophical, Religious, and Institutional Context, Prehistory to AD 1450, 2nd edition, Chicago and London, The University of Chicago Press, 2007.

[23] LosSKY, Vladimir, The vision of God, New York, St. Vladimir's Seminary Press, 1983.

[24] MANTZARIDES, George, "Tradition and Renewal in the Theology of Saint Gregory Palamas", in: Eastern Churches Review. A Journal of Eastern Christendom, George Every, John Saward, Kallistos Timothy Ware eds., Volume IX Numbers 1-2, 1977, Clarendon Press, Oxford.

[25] MEYENDORFF, John, Byzantine Theology: Historical Trends and Doctrinal Themes, revised second edition, New York, Fordham University Press, 1983 (reprinted) - The Byzantine Legacy in the Orthodox Church, Crestwood, St. Vladimir's Seminary Press, 2001.

[26] - St. Grégoire Palamas et la mystique orthodoxe, Paris: Editions de Seuil, 1959.

[27] Moschos, D.N. Platonismos ë Christianismos? Oi philosophikes prohypotheseis tou Antihësychasmou tou Nikèphorou Grigora (1293-1361), Athens: Parousia, 1998.

[28] NeSTERUK, Alexei V., Light from the East: Theology, Science, and the Eastern Orthodox Tradition, Minneapolis, Fortress Press, 2003.

[29] NiCOLESCU, Basarab, Nous, la particule et le monde, deuxième édition, revue et augmentée, Monaco, Éditions du Rocher, 2002.

[30] Palamas, Saint Gregory, The one hundred and fifty Chapters, edited and translated by Robert E. Sinkewicz, C.S.B., Pontifical Institute of Mediaeval Studies, Toronto, Ontario, Canada, 1988.

[31] —. "Hyper tõn hierõs hesychazontön", in: B. Bobrinsky, P. Papaevaggelos, J. Meyendorff \& P. Xrestou (eds.), Syggramata I, Thessaloniky: Oikos Kyromanos, 2010.

[32] - Pros Xenin monahin, în „P. Xrestou (ed.), Syggramata V, Thessaloniki: Oikos Kyromanos, 1992.

[33] - Triads, edited with an introduction by John Meyendorff, translation by Nicholas Gendle, preface by Jaroslav Pelikan, Paulist Press: New Jersey, 1983.

[34] - . 150 Capete despre cunostinta naturală, despre cunoașterea lui Dumnezeu, despre viața morală și despre făptuire (150 Chapters on natural knowledge, on knowledge of God, on moral life, and 
deeds), in Filocalia (Rom trans. of Philokalia), vol. VII, trans. by Rev. prof. Dumitru Stăniloae, Bucharest: EIBMBOR, 1977.

[35] RUSSELL, Norman, "Theosis and Gregory Palamas: Continuity or doctrinal change?", in St Vladimir's Theological Quarterly 50:4 (2006).

[36] StăNILOAE, Dumitru, Viața și învățătura Sfântului Grigorie Palama (Life and Teaching of Saint Gregory Palama), Scripta Publishing House, Bucharest, 1993.

[37] TATAKIS, Basil, Christian Philosophy in the Patristic and Byzantine Tradition, trans. by G.D. Dragas, Rollinsford, Orthodox Research Institute, 2007.

[38] VlaChos, Metropolitan Hierotheos, Saint Gregory Palamas as a Hagiorite, Levadia: Birth of Theotokos Monastery, 2000.

[39] WARE, Archimandrite Kallistos, "The Debate about Palamism", in: Eastern Churches Review. A Journal of Eastern Christendom.

[40] Williams, Rowan D., "The Philosophical Structures of Palamism", in Eastern Churches Review. A Journal of Eastern Christendom, Volume IX Numbers 1-2, 1977, Clarendon Press, Oxford.

[41] Yangazoglou, Stavros, "Philosophy and theology: The demonstrative method in the theology of St. Gregory Palamas", in The Greek Orthodox Theological Review, 41, 1 (1996). 